\title{
CAROLINA DE JESUS E QUARTO DE DESPEJO: A EXPERIÊNCIA COMO DESCONSTRUÇÃO
}

\author{
Antônio Roberto Giraldes1
}

\begin{abstract}
Resumo
A importância de Carolina de Jesus na Literatura em Língua Portuguesa e na Literatura Afrobrasileira já é, de certa forma, inquestionável. No entanto, há ainda muito que se ratificar e se desdobrar em seus textos por conta de sua riqueza, de sua ação afirmativa perante as pautas identitárias e das problematizações enunciativas que podem transcorrer na cultura, na educação e na sociedade. O presente trabalho discutirá no livro "Quarto de Despejo" as possibilidades de desconstrução e subversão tanto da organização literária quanto da produção enunciativa. Para tanto, utilizará como referência principal as noções de "escritura", "hospitalidade", "brisura" e "rátio trágica" de Jacques Derrida e sua crítica ao logocentrismo branco europeu, aplicando-as transversalmente nos conceitos de marcadores sociais da diferença.
\end{abstract}

Palavras-chave: Carolina de Jesus. Literatura Brasileira. Literatura Afro-brasileira. Logocentrismo. Desconstrução.

\section{CAROLINA DE JESUS AND THE THOWING OUT BEDROOM: EXPERIENCE AS DESCONSTRUCTION}

\begin{abstract}
The importance of Caroline de Jesus in Portuguese Language Literature and in Afro-Brazilian Literature already is, as it were, unquestionable. Though, there is still much to ratify and to explain in her texts because of the richness found on them, their affirmative action before the identity guidelines and their enunciative problematizations that can take place in culture, education and in society. The present work will discuss in the book "Bedroom of eviction" the possibilities of deconstruction and subversion both for the literary organization for enunciative production. Therefore, it will use as its main reference the notions of "scripture", "hospitality", "brisure" and "tragic ratio" by Jacques Derrida and his criticism of white European logocentrism, applying them transversally to the concepts of social markers of difference.
\end{abstract}

Keywords: Carolina de Jesus, Brazilian Literature. Afro-brazilian Literature. Logocentrism. Desconstruction.

\footnotetext{
${ }^{1}$ Mestre e Doutor em Educação na área de Mitohermenêutica e estudos do Imaginário, pela Universidade de São Paulo. ORCID http://orcid.org/0000-0002-2894-560X. E-mail: argiraldes@gmail.com
} 


\section{INTRODUÇÃO}

Não é intenção deste trabalho comentar o sucesso de vendas da obra "Quarto de Despejo" de Carolina de Jesus, nem a sua tradução para 13 línguas, nem os elogios a ela proferidos por Rachel de Queiroz, Sérgio Milliet, Helena Silveira e Manuel Bandeira. Tampouco é proposta aqui descrever seus impactos nos movimentos de políticas públicas relacionadas à questão da moradia. A intenção é perceber e articular processos de recepção do texto em uma esfera temática-estrutural, observando os "marcadores sociais da diferença" (MOUTINHO, 2014) sob a luz de Jacques Derrida e seu conceito de Escritura.

Inicialmente, podem-se considerar duas formas inaugurais de recepção da obra "Quarto de despejo": uma primeira via, entendendo Carolina como a "favelada que escreve", um milagre, "estética da carência", indicando-se que sua biografia a valoriza numa época em que havia demandas de literaturas de cunho social.

A segunda via, por outro lado, entende em Carolina uma "estética da riqueza". Tendo a autora um avô escravo de origem Bantu, recebeu uma moral-cristã. O Oficial de Justiça Manoel Nogueira (mulato) lia todas as tardes os jornais da época para os negros que não podiam ler quando Carolina era criança. O colégio em que ela fez o primário (Alan Kardec) era incentivador da leitura. Enfim, Carolina como uma contadora de histórias, seguindo a tradição recebida pelo avô e pela educação que teve.

\section{METODOLOGIA / DESCRIÇÃO DO REFERENCIAL ANALÍTICO}

Além dos dois processos de recepção elencados, pode-se também contemplar mais uma forma de recepção: a subversão da tradição literária, bem como de padrões enunciativos.

Jacques Derrida, dentre outras questões, propõe a desconstrução de uma "cegueira histórica". Para o autor, o logocentrismo ocidental, nascido da metafísica e alfabeto gregos, fundante da filosofia, reduz modelos de percepção.

Essa redução ocorre, pois, no logocentrismo, reina o princípio da identidade através da palavra, que se estabelece como "prólogo" do que se entende por "verdade". Haveria, então, a necessidade de um "desrecalcamento" da palavra ("logos" inicial), uma desconstrução, não no sentido da destruição, mas no de ampliação de repertórios e possibilidades interpretativas advindas não do ego, mas do inconsciente (acepção psicanalítica). 


\title{
Linguagens - Revista de Letras, Artes e Comunicação - ISSN 1981- 9943 \\ Blumenau, v. 15, n. 2, p. 019-037, maio./ago. 2021.
}

Nesse sentido, a produção de significação seria anterior a si própria. Derrida (1973) cria, então, o termo "Escritura". A Escritura não é decorrência da linguagem em geral, ela passa a descrever a própria linguagem, incluindo gestos físicos do ato de escrever, por exemplo. Enfim, a Escritura seria a totalidade do processo da escrita.

A "metáfora", figurativização, como possível essência dessa Escritura insere-se como momento epifânico, por conta da sua imediatez, sua transitoriedade, sua relatividade. $\mathrm{O}$ processo da escrita torna-se múltiplo. As possibilidades interpretativas transitam entre corpo, espaço, tempo, sociedade. O texto fragmenta-se no próprio contexto.

Dessa forma, o presente trabalho projetará uma interpretação da Escritura na obra "Quarto de Despejo" de Carolina de Jesus, observando a Escritura como a própria vida da autora, considerando-se três eixos temáticos ligados ao processo de escrita: o espaço (conceito de "hospitalidade"), o tempo (conceito de "brisura") e o papel ("ratio trágica"), observando-se os marcadores sociais de "favelada", "negra" e "mulher".

\section{O ESPAÇO - "HOSPITALIDADE"}

$\mathrm{Na}$ intenção de se compor uma visão mais adequada à experiência, saindo-se propriamente de um "racionalismo ativo" (BACHELARD, 2008, p. 1) para uma curta análise das imagens (metáforas) proferidas dos espaços físicos, supõe-se, inicialmente, o espaço como sendo a "Casa" e o que ela representaria dentro das imaginações literárias:

\begin{abstract}
A casa é o nosso canto do mundo. Ela é, como se diz amiúde, o nosso primeiro universo. É um verdadeiro cosmos. Um cosmos em toda acepção do termo. Vista intimamente, a mais humilde moradia não é bela? Os escritores da "casinha humilde" evocam com frequência esse elemento da poética do espaço. (BACHELARD, 2008, p. 24).
\end{abstract}

A tendência de muitos escritores é de se lembrarem da casinha pobre, a imaginação construindo paredes com sombras impalpáveis num conforto com a ilusão da proteção. Esse caráter imaginado materializa-se dentro de uma contextualização social ao transcodificar a significação originária construída quase por rastros para uma significação esclerosada do afeto primordial:

O lar era a quintessência do mundo burguês, pois nele, e apenas nele, podiam os problemas e contradições daquela sociedade ser esquecidos ou artificialmente eliminados. Ali, e somente ali, os burgueses e mais ainda a família pequenoburguesa podiam manter a ilusão de uma alegria harmoniosa e hierárquica, cercada 


\section{Linguagens - Revista de Letras, Artes e Comunicação - ISSN 1981- 9943 \\ Blumenau, v. 15, n. 2, p. 019-037, maio./ago. 2021.}

pelos objetos materiais que a demonstravam e a faziam possível. (HOBSBAWN, 2017, p. 350).

O Natal como ritual doméstico na imagem do frio europeu lá fora e as pessoas protegidas diante da fogueira, com uma árvore dentro da casa (natureza pacificada), cheia de presentes e de detalhes; a Casa Grande, cheia de cômodos plenamente separados e hierarquizados; enfim, todo um processo de composição espacial constituindo a Escritura do espaço, percebido metaforicamente pelas experiências de Carolina: “"[15 de maio - 1956] ...Eu classifico São Paulo assim: o Palacio, é a sala de visita. A Prefeitura é a sala de jantar e a cidade é o jardim. E a favela é o quintal onde jogam os lixos". (JESUS, 2014, p. 32).

Quanto à consideração de Carolina sobre esse marcador social, há sentidos direcionados à hierarquia espacial (Palácio-sala de visita, Prefeitura-sala de jantar, Cidadejardim), nota-se tal percepção a partir da experiência de seus vizinhos dizerem que os políticos protegem os favelados. Ela comenta que essa proteção não ocorre, dizendo até o nome de um político: Cantídio Sampaio (hoje nome de uma grande avenida em São Paulo), que prometeu e não cumpriu.

Sua consciência hierárquica vem de se sentir colocada à margem da construção do lar burguês advinda da "Era do Capital" de Hobsbawm, lar esse, afetivamente ligado a uma cosmologia inicial em que se basearia nossa primeira essência. Ela é uma pessoa à cata de um lar tal como atrás de si mesma: “[27 de julho - 1955] É que eu estou escrevendo um livro, para vendê-lo. Viso com esse dinheiro comprar um terreno para eu sair da favela. Não tenho tempo para ir na casa de ninguém”. (JESUS, 2014, p. 27).

A Escritura de Carolina é sobre a ausência de espaço-casa, um percurso para um lugar afetivo fixo. Esse percurso permanece na obra posterior "Casa de Alvenaria" (JESUS, 1961). Carolina, um tempo depois, com o dinheiro da venda de seus livros, compra uma casa no bairro de Parelheiros - São Paulo, casa que lembra um sítio, mais parecido como da sua infância em Minas Gerais, ou seja, um reencontro com o rastro do amparo da infância na constituição de sua essência.

No entanto, é possível que ela constituísse uma percepção de que seu lugar social estava mais na Escritura que no prédio físico:

Decepção. Pensei que houvesse mais idealismo, menos inveja. Mas aqui há não só muita ambição, mas também o desejo de vencer a qualquer preço. Mesmo que os meios empregados sejam pobres. Quando matei um porco, lá na favela do Canindé, alguns vizinhos exigiram um pedaço de carne. Rondavam meu barraco feito bicho que fareja presa. Lá na favela era o porco, aqui é o dinheiro. No fundo é a mesma 
coisa. Lembrei do meu provérbio: "Não há coisa pior na vida do que a própria vida". (JESUS, 2014, p. 197).

Isso foi comentado por Carolina quando perguntada de como era o mundo fora da favela. Um início dessa noção trágica de mundo tanto na favela quanto fora dela, possivelmente, já ocorria durante a Escritura de "Quarto de Despejo", pois há referências do processo de publicação de "Quarto de Despejo" no próprio livro, houve as reportagens na "Folha da Noite" em 1958 e na "Revista Cruzeiro" em 1959 antes da efetiva publicação de “Quarto de Despejo" em 1960:

[13 de junho - 1959]

- Ela saiu no O Cruzeiro. Com ela agora é mais Cruzeiro.

- Eles te pagaram?

- Vão dar-me uma casa.

- Vai esperando! (JESUS, 2014, p. 173).

Se não há nada pior na vida do que a própria vida, de que vale um lar, uma casa, um espaço? Essa percepção da felicidade ilusória através de um lar permite, de certa forma, uma errância, dentro do processo de composição:

\footnotetext{
A palavra "hospitalidade" vem aqui a traduzir, levar adiante, re-produzir, as outras duas palavras que lhe tem precedido, "atenção" e acolhida" [...] uma série de metonímias dizem a hospitalidade, o rosto, a acolhida: a tensão para com o outro, intenção atenta, atenção intencional, sim ao outro. (DERRIDA, 1995, p. 72).
}

Derrida amplia o conceito metafórico na Escritura de "casa" como "lar" (algo que nos protege) para o de "hospitalidade", lugar de atenção e acolhida do "outro", algo presente na noção arcaica de xênia, ou seja, a casa, além de ser um lugar de proteção das intempéries do frio e da chuva, torna-se um espaço de acolhimento do outro. Deduz-se, de certa forma, que Carolina acreditava, ao sair da favela, acolher e ser acolhida pelo "outro", uma vez que a favela remete à situação de rua, algo entre o ambiente fixo e confortável e a invisibilidade social do caminhante fragilizado: "não posso nem receber e nem ser recebido quando estou na quase-rua, já, quando possuir uma casa, terei contato efetivo com o 'outro"”, ou seja, ela teria uma troca de marcador social, que lhe permitiria uma proximidade com o "outro". Mas quem será esse "outro"?

Há referências também no diário sobre o "outro". Por conta disso, interseccionam-se os marcadores sociais "favelada" e "mulher". 


\section{Linguagens - Revista de Letras, Artes e Comunicação - ISSN 1981- 9943 \\ Blumenau, v. 15, n. 2, p. 019-037, maio./ago. 2021.}

[15 de julho - 1955]

Esperei até as 11 horas, um certo alguém. Ele não veio. Tomei um melhoral e deiteime novamente. (JESUS, 2014, p. 11).

[21 de julho - 1955]

- Seu marido onde trabalha?

- Não tenho marido, e nem quero! (JESUS, 2014, p. 23).

[27 de julho - 1955]

...Seu Gino veio dizer-me para eu ir no quarto dele. Que eu estou the despresando. Disse-lhe: Não!

É que eu estou escrevendo um livro, para vendê-lo. Viso com esse dinheiro comprar um terreno para eu sair da favela. Não tenho tempo de ir na casa de ninguém. Seu Gino insistia. Ele disse:

- Bate que eu abro a porta.

Mas o meu coração não pede para eu ir no quarto dele. (JESUS, 2014, p. 27).

[16 de janeiro - 1959]

Olhei o rosto do cigano. O rosto bonito. Mas fiquei com nojo. Era um rosto de anjo com alma de diabo. (...) Vim para meu barraco. Eu estava pondo os cadernos em cima da mesa, quando senti que alguém me pegava pelas costas. Era o cigano que me abraçava. Beijou-me na boca. Os seus braços me apertavam tanto. Disse-me:

- Eu vou-me embora. Deixo as minhas roupas. Você lave-as para mim [...] Sei que você vai pensar em mim e sei que vai sentir falta de mim. Sei que vou ser hospede do teu coração. (JESUS, 2014, p. 157).

[16 de janeiro - 1959]

Estou decidida: quando o cigano voltar, hei de apresentá-lo a Dona Lei. Dizem que o cigano não pode ficar parado. Mas a Dona Lei há de fazer ele estacionar uma temporada atrás das grades. (JESUS, 2014, p. 158).

[13 de agosto - 1959]

O senhor Manoel apareceu.[...]

- Você não me quer mais?

- Eu tenho muito serviço. Não posso preocupar com homens. Meu ideal é comprar uma casa decente para meus filhos. Eu nunca tive sorte com homens. Por isso não amei ninguem. Os homens que passaram na minha vida só arranjaram complicações para mim. Filhos para eu criá-los. (JESUS, 2014, p. 189).

O Cigano se dispõe a "hospedar-se" no coração de Carolina. A consciência trágica dela percebia a errância que o senso comum dá ao termo "Cigano" no sentido de ele ficar "hospedado" na cadeia, forma de paralisar o sentido errante do termo. Ele é, de certa forma, uma metonímia das experiências que Carolina passou com homens e da postura que ela adquire quanto a eles.

Num contexto onde os negros nunca podiam prever quanto tempo estariam juntos, que forma o amor tomaria? Praticar o amor nesse contexto poderia tornar uma pessoa vulnerável a um sofrimento insuportável. De forma geral, era mais fácil para os escravos se envolverem emocionalmente, sabendo que essas relações seriam transitórias. A escravidão criou no povo negro uma noção de intimidade ligada ao sentido prático de sua realidade. Um escravo que não fosse capaz de reprimir ou conter suas emoções, talvez não conseguisse sobreviver. (HOOKS, 2010, p. 1). 
Linguagens - Revista de Letras, Artes e Comunicação - ISSN 1981- 9943

Blumenau, v. 15, n. 2, p. 019-037, maio./ago. 2021.

De certa forma, receber e acolher, diante da precariedade da casa e do outro, pode ser perigoso. 


\title{
Linguagens - Revista de Letras, Artes e Comunicação - ISSN 1981- 9943 \\ Blumenau, v. 15, n. 2, p. 019-037, maio./ago. 2021.
}

\begin{abstract}
A hospitalidade se apresenta, antes de mais nada, como o ato de receber o outro, um ato desmesurado, no qual se recebe para além da capacidade do eu; mas, também, ela nos revela com uma dupla face, com uma ambiguidade que lhe é constitutiva, com alguma coisa que é tanto limitada quanto ilimitada. (SKLIAR, 2008, p. 28).
\end{abstract}

A ambiguidade da "hospedagem" vem da concepção, num primeiro momento, de incondicionalidade, ou seja, daquele que hospeda o estrangeiro sem nenhuma pergunta; no ato de comunicação, hospeda-se o "sentido-outro" sem reservas. Num segundo momento, impõem-se condições para a hospedagem: o "outro" deve revelar suas intenções ao hóspede, deve falar a língua do hospedeiro, deve apresentar a documentação aduaneira, dentre outros. A questão seria a saída do binarismo eurocêntrico das duas concepções anteriores para algum terceiro elemento:

\begin{abstract}
Essa conceitualidade traz em acréscimo a noção de "exapropriação", que se apresenta como suplemento desconstrutor toda vez que surge esse movimento que impele o sujeito para a autofabricação de seu "domínio" interno. Exapropriação é o duplo movimento da subjetividade em direção ao sentido na tentativa de apropriá-lo, mas, ao mesmo tempo, sabendo e desejando que continue estrangeiro, transcendente, que permaneça lá onde só há alteridade. (CARVALHO, 2005, p. 208).
\end{abstract}

Se o sentido do mundo pudesse ser apropriado totalmente, exaustivamente, sem rastros ou vestígios, deixaria de existir. Daí a desconstrução do próprio sentido e da produção do movimento das significações, a aplicação do prefixo "ex". Nesse sentido, é bem pertinente o subtítulo da "Casa de Alvenaria" ser "Diário de uma ex-favelada" (JESUS, 1961).

Uma vez que Carolina morou em uma favela e optou por escrever sobre essa experiência, permitindo-se, corajosamente, seguir a empiria da palavra escrita até nos próprios papéis que recolhia, caminhou por esse mundo labiríntico da favela como "quase-moradia", metaforizando-a em um "quarto", mas um "quase-quarto", "quarto de despejo".

A busca de sentido continua em Casa de Alvenaria, todavia, a percepção trágica de que em todos os lugares não há lugar seguro e acolhedor, uma hospedaria plena, pois "a própria vida já é o pior de si mesma”, impõe à Carolina seu caminho, novamente, através das palavras e de suas Escrituras, de certa forma uma estrangeira em terra própria, uma migrante em seu aspecto trágico:

Um estilo é conseguir gaguejar na sua própria língua. É difícil, porque é preciso que exista necessidade de um tal gaguejar. Não ser gago nas suas palavras, mas ser gago na própria linguagem. Ser como que um estrangeiro na sua própria língua. Traçar uma linha de fuga. (DELEUZE; PARNET, 2004, p. 15). 
Por conta disso, nota-se que a mera troca de marcador social de "favelada" para "moradora numa casa", não modifica o sentido trágico de Carolina. Isso ocorre por existirem outros marcadores sociais, pela relação ambígua com a hospedagem do outro, pelos rastros identitários por que ela permeia. Carolina segue como uma migrante em sua própria terra, caminhando na produção de significação:

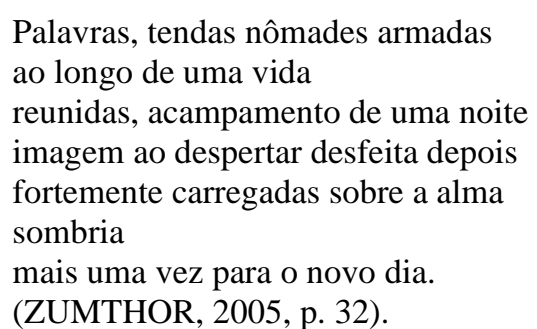

Toda essa complexa rede de interpretações descrita sobre a questão da casa e da hospitalidade projeta-se diretamente também no processo de enunciação e de Carolina e na sua relação com o leitor: “[18 de julho - 1955] Nunca feri ninguem. Tenho muito senso! Não quero processos. O meu rigistro geral é 854.936".

Cabe salientar que ao número do RG (Registro Geral) são indexadas as ocorrências criminais. Carolina, nesse trecho se coloca, de certa forma, como uma estrangeira na própria terra (própria casa e próprio texto), como uma hóspede, sugerindo: "Se você quiser, pode consultar meus antecedentes criminais com o meu número de RG”, ou seja, "até no meu livro preciso de um número de registro geral da sociedade que hospede minha identidade.

\section{O TEMPO - "BRISURA"}

Uma Escritura, mais que uma imitação de algo transcendente é, em si, a própria construção da significação do instante. No instante, encontra-se a performance concreta. Daí advém a importante relação do "espaço" com o "tempo", uma vez que o "tempo" traz uma suplementação para se entoar essa noção de "espaço", vivida por Carolina.

Como sugerido anteriormente, quando se possui um espaço fixo e definido, pode ocorrer uma imobilidade de percepções de outros espaços e indivíduos. Se, por um lado, há a perda de porosidades na escuta do outro, por outro lado, para o capitalismo, um espaço fixo permite não somente o acúmulo de patrimônio na noção de propriedade, mas também o crescimento desse acúmulo na passagem do tempo. 
Com um espaço delimitado, uma casa própria comprada, o indivíduo pode investir e calcular seu projeto de vida em anos (lucros a longo prazo, formação universitária, composição da família, dentre outros). Todavia, se um indivíduo não possui o espaço fixo que a sociedade lhe cobra, passa, cotidianamente, pensando em qual lugar dormirá ou se protegerá dali a um mês, uma semana, um dia. Pior fica a situação de Carolina, na qual ela acorda com o desafio de conseguir comida e dorme a cada noite, escrevendo no seu diário, vitoriosa por ter sobrevivido um dia a mais:

\footnotetext{
[15 de julho - 1955]

Passei o dia indisposta. Percebi que estava resfriada. A noite o peito doia-me. Comecei tossir. Resolvi não sair a noite para catar papel. Procurei meu filho João José. Ele estava na rua Felisberto de Carvalho, perto do mercadinho. O ônibus atirou um garoto na calçada e a turba afluiu-se. Ele estava no nucleo. Dei-lhe uns tapas e em cinco minutos ele chegou em casa.

Ablui as crianças, aleitei-as e ablui-me e aleitei-me. Esperei até as 11 horas, um certo alguem. Ele não veio. Tomei um melhoral e deitei-me novamente. Quando despertei o astro rei deslisava no espaço. A minha filha Vera Eunice dizia: - Vai buscar agua mamãe! (JESUS, 2014, p. 11).
}

A quantidade de informações implícitas nesse trecho é de dar inveja a qualquer boa dramaturgia, um monólogo perfeito e denso. Aquele dia não estava bom (tosse e indisposição, quase como um prenúncio de perigo). Por conta disso, Carolina não saiu à noite para trabalhar. Numa intuição de mãe, foi atrás do filho. Ela informa onde o filho está num período simples e curto. Logo após, comunica o atropelamento de um garoto, mas o menino não era o filho dela, misto de alívio (por não ser seu filho) e tristeza (pelo atropelamento de um garoto).

Carolina, então, aleita (dá leite e leito), ablui (lava). Princípios claros do que se faz com um filho e também com um hóspede querido. Tudo para se proteger daquele dia perigoso. Carolina também espera o certo alguém (o "outro", o "hóspede") para o quase-lar a se constituir. Mas o "alguém" não vem, ela então toma um "melhoral", tanto para se medicar do resfriado quanto da solidão da falta de "hóspede".

Vem então o "astro rei" deslizando no "espaço" e no "tempo", indicando tanto mais um dia sobrevivido quanto mais um dia a sobreviver. Não é por acaso que o gênero escolhido é o Diário, sendo sempre o espaço de um dia o mais importante (efeméride). O instante participa ao leitor o tamanho da concretude da vida, opondo-se às Memórias, ao Romance, à Novela, gêneros que tendem a diminuir o instante cotidiano palpável e se projetam sobre os pensamentos e dilemas metafísicos das personagens. Para alguns autores, dentro do pensamento moderno, há uma grande dificuldade de percepção do instante cotidiano: 


\title{
Linguagens - Revista de Letras, Artes e Comunicação - ISSN 1981- 9943 \\ Blumenau, v. 15, n. 2, p. 019-037, maio./ago. 2021.
}

Do cotidiano, em que há pouca "terra incógnita", temos a tendência a não reter mais que o anedótico ou o superficial. Comentando a fórmula evangélica: "O pão nosso de cada dia nos dai hoje". C. G. Jung notou que existiram dificuldades para traduzila; a expressão "de cada dia" não se encontra mais que nesse lugar, e recorda que São Jerônimo havia proposta a expressão gnóstica "pão supra-substancial”! Essa associação deixa claro e sublinha bem que o cotidiano é o verdadeiro princípio de realidade, melhor ainda, da surrealidade. (MAFFESOLI, 2003, p. 7).

Carolina vem ensinar que, muitas vezes, o cotidiano é visto de forma anedótica e superficial, demonstrando o quanto ele, para ela, é real e trágico. A autora traz a concretude aos romancistas sonhadores de plantão, produtores de romances baseados em outros romances, tautologia de retorno eterno a uma metafísica em que o espaço/romance é herdado dinasticamente e o tempo dilatado a bel-prazer. Quando se quebra essa tautologia clássica do tempo, surge a "brisura" delimitada por Derrida:

\footnotetext{
Origem da experiência do espaço e do tempo, esta escritura da diferença, este tecido do rastro permite à diferença entre o espaço e o tempo articular-se, aparecer como tal na unidade de uma experiência (de um "mesmo" vivido a partir de um "mesmo" corpo próprio). Portanto, esta articulação permite a uma cadeia gráfica ("visual" ou "tátil", "espacial") adaptar-se, eventualmente de forma linear, sobre uma cadeia falada ("fônica", "temporal”). (DERRIDA, 1973, p. 80)
}

Para Derrida, "brisura" se dá na relação entre espaço e tempo. Quem estabelece essa "quase-articulação" é a experiência, projetada sobre o processo de escrita. Mais do que uma inclinação às discussões do signo saussureano e suas derivações em Lacan e Freud advindos do conceito de "brisura", seria interessante um avizinhamento à questão do eixo temporal ligado à composição da escrita:

\begin{abstract}
Os conceitos de "presente", de "passado" e de "futuro", tudo o que nos conceitos de tempo e história deles supõe a evidência clássica - o conceito metafísico de tempo geral - não pode descrever adequadamente a estrutura de rastro. E desconstruir a simplicidade da presença não acarreta somente levar em conta os horizontes de presença potencial, e mesmo de uma "dialética" da propensão e da retensão que se instalaria no coração do presente em vez de contorná-lo. (DERRIDA, 1973, p. 82).
\end{abstract}

Desconstrói-se, dessa forma, a noção temporal clássica, partindo, pelo conceito de "brisura" em que:

O "agora" B seria enquanto tal, constituindo-se pela retenção do "agora" A e pela propensão do "agora" C; apesar de todo o jogo que se seguiria, do fato que cada um dos três "agora" reproduz nele mesmo esta estrutura, este modelo de sucessividade proibiria que um "agora" X tomasse lugar do "agora" A, por exemplo, e que, por um efeito de retardamento inadmissível para a consciência, uma experiência seja 


\section{Linguagens - Revista de Letras, Artes e Comunicação - ISSN 1981- 9943 \\ Blumenau, v. 15, n. 2, p. 019-037, maio./ago. 2021.}

determinada em seu próprio presente, por um presente que não a teria precedido imediatamente mas ser-lhe-ia amplamente "anterior". (DERRIDA, 1973, p. 82).

Um Diário, por si só, já presentifica ações, porém, muitas vezes, essas mesmas ações são linearizadas tanto pela linha física do texto e da fala, quanto pela marcação das datas a demonstrarem a linha reta do calendário judaico-cristão. No entanto, há em Carolina uma sutil subversão até ao gênero do Diário, pelo fato de se poder misturar muitas daquelas datas sem que haja, necessariamente, um estranhamento temporal, ou seja, sugere muitas vezes uma noção de circularidade ao invés de linearidade. Reescreve-se a noção de tempo, penetra-se no cotidiano a se repetir um eterno presente, uma eterna procura por comida e proteção, uma eternidade alinhavada pelo rastro temporal, ou seja, a "brisura". carregava agua desde as 4 horas da madrugada, que ela lavava toda roupa em casa. Que ela precisa pagar 20 cruzeiros por mês. Minha lata encheu, eu vim embora. ... Estive revendo os aborrecimentos que tive esses dias (...) Suporto as contingências da vida resoluta. Eu não consegui armazenar para viver, resolvi armazenar paciência. (JESUS, 2014, p. 18).
}

Carolina escreveu lembrando-se do momento em que a água começou a diminuir na torneira. Teve a sensação de falta. Junto a isso, escutou os comentários sobre Rosa: uma recursiva ladainha de lamentos da atitude da vizinha (que ela carregava... que ela lavava .... que ela precisa....). A Escritura aqui apresenta os rastros temporais entre o ato da escrita, a lembrança da água faltando na torneira, os repetidos comentários de outras repetidas ações de Rosa em outro tempo. O reforço da penúria, imutável, perceptível pelos "quês", fez com que Carolina fosse embora.

Mas, mesmo se indo, posteriormente, ela escreve sobre sua ida, a recursividade e a falta de água. Decorreram, então, daí a "revisão" ou "revivência", pela memória e pela escrita, de outras atribulações que experimentou ligadas à eterna falta de futuro: ela eternamente suporta. Ela não conseguiu armazenar nada que a sociedade capitalista exige, armazenou, todavia, paciência.

O que seria, então, uma possível significação de "paciência" no contexto, senão como a arte de deixar o tempo passar como se a vida fosse um eterno e "diário" presente? A maior arma de sobrevivência de Carolina é não pensar no tempo, apenas observá-lo, quase como que o olhando de soslaio, misturando-o nas anotações de seu Diário. O presente, o passado e o futuro são bem diferentes para quem vive em uma favela, uma possível percepção da 
"brisura" , já que a paciência pode muito bem ser esse rastro temporal, sendo ela que articula o passado, o presente e o futuro.

\title{
5 PAPEL - (RATIO TRÁGICO)
}

O papel e sua relação com a escrita e, posteriormente, com o valor de troca é um elemento bem presente no conceito de urbanização e da hierarquização das cidades:

\begin{abstract}
Os estudiosos designaram Arcaica a Época em cujos umbrais Hesíodo viveu e compôs seus cantos. Na Grécia, os séculos VIII-VII a.C. testemunharam a germinação ou transplante de instituições sociais e culturais cujo florescimento ulterior transmutaria revolucionariamente as condições, fundamentos e pontos de referência da existência humana: a "pólis", o alfabeto e a moeda. (TORRANO, 1991, p. 13).
\end{abstract}

Esses três elementos: cidade, alfabeto e moeda compõem-se em uma articulação de identidades dentro do universo urbano. A cidade como elemento sensível na relação tempo/espaço é formulada e organizada pelo alfabeto (oral e escrito) e pela moeda (dinheiro).

[15 de julho - 1955]

Eu não tinha um tostão para comprar pão. Então eu lavei 3 litros e troquei com o Arnaldo. Ele ficou com os litros e deu-me pão. Fui receber o dinheiro do papel. Recebi 65 cruzeiros. Comprei 20 de carne. 1 quilo de toucinho e 1 quilo de açucar e seis cruzeiros de queijo. E o dinheiro acabou-se. (JESUS, 2014, p. 110).

Carolina não tinha "um tostão", o "papel-dinheiro". Foi receber o "papel-dinheiro" trocado pelo "papel-catado". Ela diz que, posteriormente à troca, o "papel” acabou-se. No entanto, nesse mesmo "tempo e espaço" ela escreve em um papel também catado o "papeldiário". Papel esse que ela deseja tornar um espaço/tempo para sua morada no futuro, quando da publicação, uma vez que ela já tinha a intenção de publicar antes mesmo de conhecer Audálio Dantas (o jornalista que se dispôs ajudá-la). Durante o Diário, ela comenta que já tinha enviado à "Reader's Digest” os exemplares, negados pela editora. Carolina até estranha uma mudança do "papel-dinheiro" para o "metal-dinheiro":

[24 de outubro - 1958]

...Eu fiz café e mandei o José Carlos comprar 7 cruzeiros de pão. Dei-lhe uma cédula de 5 e 2 de aluminio, o dinheiro que está circulando no paiz. Fiquei nervosa quando contemplei o dinheiro de aluminio. $\mathrm{O}$ dinheiro devia ter mais valor que os generos. E no entretanto os generos tem mais valor que o dinheiro.

Tenho nojo, tenho pavor

Do dinheiro de aluminio 
O dinheiro sem valor

Dinheiro do Juscelino.

(JESUS, 2014, p. 126).

Carolina estava acostumada com o papel e o que o papel lhe possibilitaria, parece que o alumínio não funcionaria tão bem nessa "troca de papéis", notando-se que essas trocas eram diretas, sem uma consciência de acumulação. Em geral, o dinheiro que entrava já possuía um destino certo: comida.

\footnotetext{
No mundo da favela, o que se vive é a concretude da pobreza mais absoluta. Nesse lugar, à beira da cidade letrada e do sistema capitalista, as relações de troca são diretas, praticamente sem a mediação da "terceira mercadoria", que é o dinheiro. Muitas vezes Carolina troca a lata, o papel, diretamente por algum gênero alimentício ou de primeira necessidade. (SOUSA, 2012, p. 88).
}

A acumulação do papel-moeda relaciona-se com a dilatação do tempo, transcendendose o dia a dia; a dilatação do espaço, fixando-se no lugar-casa-hospitaleira e a dilatação da Escritura, transformando-se um "diário" em "memórias". No entanto, para Carolina, o reforçar o valor do papel do cotidiano e o questionar a valoração de outro tipo de dinheiro demonstram a insistência que ela possui na sua noção de moeda, adulterando essa noção de acumulação de moeda não como forma de alienação, mas como percurso de construções de outras realidades. Permitindo-se aqui um paralelo com Diógenes - o Cínico, conta-se que o

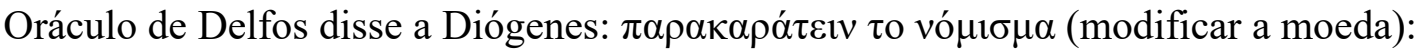

\footnotetext{
A palavra usual "nómisma" associa-se a dois significados: (1) indica a unidade monetária vigente, isto é, as "moedas", e (2) denota "costumes", "instituições", "valores aceitos" [...] assim, o significado exato do oráculo dado a Diógenes, conforme os relatos é "desfigurar a moeda vigente". (NAVIA, 2009, p. 42).
}

Diógenes tentou descaracterizar a moeda ou a efígie da moeda como diria Gros (2011), como se fosse um estrangeiro errante. Comenta-se que Diógenes perdeu a choupana em que vivia (hospedagem) e decidiu viver em um tonel, caminhando com uma lanterna à cata de um ser humano de verdade.

É essa verdade imediata levantada por Carolina. A escritora possuiria a consciência de sua escrita como elemento modificador da efígie, de valores e da tradição logocêntrica.

Eu era revoltada, não acreditava em ninguém. Odiava os políticos e os patrões, porque o meu sonho era escrever e o pobre não pode ter ideal nobre. Eu sabia que ia angariar inimigos, porque ninguém está habituado a esse tipo de literatura. Seja o que Deus quiser. Eu escrevi a realidade. (JESUS, 2014, p. 197). 
Dois pontos podem ser levantados referentes aos comentários que a autora faz de si. Ela própria se considera outro tipo de literatura, uma literatura diretamente ligada à realidade, diferente do que se tinha por costume, do caráter inventivo ou analítico do processo de escrita. Ora, para o senso comum, a grande diferença do escritor para o jornalista é exatamente essa reconstrução da realidade: o jornalista escreve a realidade enquanto o escritor reconstrói a realidade; estando exatamente aí o "éthos" autoral do escritor a marcar a tradição e conseguir seguidores. É interessante também comentar que Carolina conhecia bem Castro Alves, Camões, José de Alencar, escritores com o caráter inventivo de reconstrução da realidade bem evidente.

O segundo ponto é a utilização gênero Diário, não necessariamente entendido como algo estritamente literário, uma espécie de escrita dos excluídos diante da tradição literária do gênero "Memórias" tão amplamente utilizada. Isso é até recursivo em Carolina, pois, além de “Quarto de Despejo”, ela escreveu: “Casa de Alvenaria” (1961), "Diário de Bitita” (1986), "Meu estranho Diário" (1986).

Essa aproximação com a realidade, espécie de "metáfora direta", surge como processo de desconstrução de modelos literários prévios, mais propensos a uma tradição em que se catalogam estéticas, sentimentos e produções a serem limitadas a um jogo de significados prontos, contemplados apenas pela inteligência e imaginação do escritor. Virtudes essas que lhe dão o princípio de autoria.

É como se existisse o mesmo piano com as mesmas notas musicais de sempre e os compositores, alterando a velocidade e as combinações dessas notas, produzissem, por um lado algo novo, mas, por outro lado, algo já esperado, por conta de nossos ouvidos acostumados àquelas sonoridades.

A desconstrução é a busca de outras notas musicais ou até de algo que transcenda a própria noção de nota musical. Como ferramentas desse trabalho, Carolina possui o papel e a experiência projetando-se sobre o tempo e o espaço:

O lugar social não determina uma consciência discursiva sobre esse lugar. Porém, o lugar que ocupamos socialmente nos faz ter experiências distintas e outras perspectivas. [...] Busca-se aqui, sobretudo lutar para romper com o regime de autorização discursiva. (RIBEIRO, 2017, p. 39). 
O discurso autorizado e único cuja pretensão é a universalidade solapa o oprimido, tirando-lhe o tempo, o lugar e a voz, deixando-lhe apenas papéis jogados na rua. Carolina fala através desses papéis, transcodifica-os. Sua arma são as experiências distintas que possui, são elas o seu lugar, o seu tempo e o seu papel. Não interessaria à Carolina as notas musicais prontas do piano, ela cria novas sonoridades a partir de suas experiências cotidianas, tal como fez Elza Soares ao descobrir sua voz cantando para si mesma com uma lata d'água na cabeça. (LOPES, 2018, p. 21).

[27 de maio - 1958]

...Resolvi tomar uma media e comprar num pão. Que efeito supreendente faz a comida no nosso organismo! Eu que antes de comer via o céu, as árvores, as aves tudo amarelo, depois que comi, e tudo normalizou-se aos meus olhos.

... A comida no estomago é como o combustível nas maquinas. (JESUS, 2014, p. $44)$.

Quando comeu, o corpo de Carolina deixou de pesar e ela andou mais depressa, parecia que deslizava no espaço, sorriu ao presenciar um belo espetáculo. "A fome é amarela!". Metáfora direta e plena com a experiência distinta. A autoridade ao se falar sobre a fome é diferente quando vem de alguém que propriamente passa fome. Contundente efeito de lugar de fala. A afirmação de Carolina está na experiência distinta valorizada e no texto redimensionado para essa experiência.

Dificilmente um escritor bem alimentado, dinasticamente protegido por um nome de família da elite intelectual, chegaria a essa "metáfora amarela", por mais sensível e preocupado com o hiato social brasileiro que estivesse. Essa limitação é aventada por Derrida em sua crítica a Lévi-Strauss:

Derrida aponta o quanto Lévi-Strass é marcado por aspectos logocêntricos e por uma metafísica da presença implacável em seu pensamento. Esta surge em momentos cruciais da obra do antropólogo e irá, portanto comprometer Lévi-Strauss com o enclausuramento metafísico. (MORAES, 2013, p. 143).

Claude Lévi-Strauss observa que os povos indígenas não possuem escrita, no entanto, ao perceber os Nhambiquaras escreverem, afirma que estão imitando seus gestos, classificando-os como rabiscos ou traços, dos quais os Nhambiquaras não tinham consciência. Para Derrida, essa postura mantém o distanciamento e a hierarquização entre uma cultura e outra. 
Coisa estranha é a escrita. Tudo indicaria que sua aparição não poderia deixar de determinar mudanças profundas nas condições de vida da humanidade; e que essas transformações deveriam ser, acima de tudo, de natureza intelectual. A posse da escrita multiplica fantasticamente a capacidade dos homens para preservar os conhecimentos. (LÉVI-STRAUSS, 1996, p. 318).

A crítica está justamente inserida na concepção de que a escrita multiplica a capacidade dos homens de conservar os conhecimentos percebidos pela própria escrita, em outras palavras, colocar óculos possibilita que a pessoa enxergue mais e que ela conheça mais o mundo visual, mas não significa, necessariamente, que ela conheça mais o mundo em si.

De um ponto de vista de Lévi-Strauss, Carolina pode somente ter rabiscado ou tracejado uma escrita, imitando modelos textuais, sem muita consciência. Derrida demonstra que essa é uma visão hierárquica e logocêntrica, na qual já se tem pronto o que pode ser feito da cultura escrita.

\section{CONSIDERAÇÕES FINAIS - A VIOLÊNCIA DA LETRA}

Longe de encerrar uma leitura absoluta do texto de Carolina de Jesus, esse trabalho pretendeu demonstrar que, dentro da recepção de um texto, há que se considerar também a relação entre "texto-leitor-processo de leitura".

Nenhuma leitura é ingênua. O leitor, ao ler o texto, de certa forma, reescreve-o para si, para os padrões de suas compreensões de mundo e de seus marcadores sociais introjetados. No entanto, as dinâmicas sociais e os processos afirmativos advindos das pautas identitárias fundamentam protagonismos de Escrituras até então desconsideradas anteriormente. Esses protagonismos favorecem alterações no texto, no leitor e no processo de leitura, sugerindo uma quebra da hierarquia implícita produzida pelo próprio texto.

Dessa forma, o próprio elemento inicial de opressão e hierarquia social torna-se instrumento de subversão de si próprio (modifica-se a efígie). Carolina de Jesus produz muito mais que um texto, produz contextos e leituras novos e provoca, com suas quebras atordoantes, novas formas de processos de leituras. Cabe ao leitor acreditar-se parte do processo e permitir-se ampliar sua escuta, sua visão, seu lugar, seu tempo e sua palavra. 


\section{REFERÊNCIAS}

BACHELARD, Gaston. A poética do espaço. Tradução: Antônio de Pádua Danesi. 2. ed. São Paulo: Martins Fontes, 2008.

CARVALHO, Luiz Fernando Medeiros de. Sobre a hospitalidade. In: NASCIMENTO, Evando (org.). Jacques Derrida - Pensar a desconstrução. São Paulo: Estação Liberdade, 2005 .

DELEUZE, Gille; PARNET, Claire. Diálogos. Tradução: José Gabriel Cunha. Lisboa: Relógio D’Água Editores, 2004.

DERRIDA, Jacques. El linguaje y las instituciones filosóficas. Barcelona: Editorial Paidós, 1995.

DERRIDA, Jacques. Gramatologia. Tradução: Miriam Schnaiderman e Renato Janini Ribeiro. São Paulo: EDUSP / Perspectiva, 1973.

GROS, Frédéric (org.). Foucault. A coragem da verdade. Tradução: Eduardo Brandão. São Paulo: Editora WMF Martins Fontes, 2011.

HOBSBAWM, Eric J. A era do capital. Tradução: Luciano Costa Neto. Rio de Janeiro: Paz e Terra, 2017. 26. ed.

HOOKS, Bell. Vivendo de amor. Portal Legedés. [S. l.], 9 mar. 2010. Tradução: Maísa Mendonça. Disponível em: https://www.geledes.org.br/vivendo-de-amor/ Acesso em: 14 dez. 2020.

JESUS, Carolina Maria de. Casa de alvenaria - diário de uma ex-favelada. Rio de Janeiro: Francisco Alves, 1961.

JESUS, Carolina Maria de. Quarto de despejo - diário de uma favelada. 10. ed. São Paulo: Ática, 2014.

LÉVI-STRAUSS, Claude. Tristes trópicos. Tradução: Rosa Freire d’Aguiar. São Paulo: Companhia das Letras, 1996.

LOPES, João Carlos. Elza Soares: vida e obra sob o olhar da fonoaudiologia. 2018. 124 p. Tese (Doutorado em Fonoaudiologia) - Pontifícia Universidade Católica, São Paulo, 2018.

MAFFESOLI, Michel. O instante eterno - O retorno do trágico nas sociedades pósmodernas. Tradução: Rogério de Almeida e Alexandre Dias. São Paulo: Zouk, 2003.

MORAES, Marcelo. A crítica de Derrida ao etnocentrismo não declarado de LéviStrauss. Ensaios Filosóficos, Rio de Janeiro, v. 7, p. 137-155, abr. 2013.

MOUTINHO, Laura. Diferenças e desigualdades negociadas: raça, sexualidade e gênero em produções acadêmicas recentes. Cadernos Pagu, [s. l.], v. 42, p. 201-248, jan.-jun. 2014. 
NAVIA, Luis E. Diógenes, o cínico. Tradução: João Moreira Auto. São Paulo: Odysseus, 2009.

RIBEIRO, Djamila. O que é lugar de fala? Belo Horizonte: Letramento, 2017.

SKLIAR, Carlos. Derrida \& a educação. Belo Horizonte: Autêntica, 2008.

SOUSA, Germana Henriques Pereira de. Carolina Maria de Jesus: o estranho diário da escritora vira lata. Vinhedo: Horizonte. 2012.

TORRANO, Jaa. Teogonia - a origem dos deuses. Estudo e Tradução da Teogonia de Hesíodo. São Paulo: Iluminuras, 1991.

ZUMTHOR, Paul. Escritura e nomadismo. Tradução: Jeruza Pires Ferreira e Sonia Queiroz. Cotia: Ateliê Editorial, 2005. 